\title{
猃 壇
}

\section{触法精神障害者対策の問題点}

司法精神医学の確立を願う

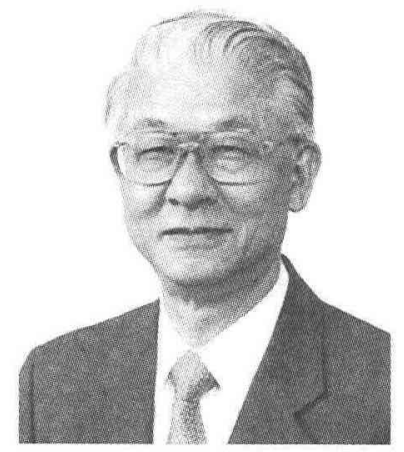

高橑 清久

今年の6月に大阪教育大学付属小学校の多数の児 童が殺傷されるという大变痛ましい出来事があっ た。犯人に精神病院への入院歴があったために一 時は精神障害者の犯罪ということで、社会の精神 障害者への危険視が強くなった。しかし、犯人の 詳細が明らかにされるに従い精神障害者の犯罪と いえるかどうかの疑問が生じ、現在精神鑑定が行 われている。今回の事件を通じて、触法精神障害 者の問題が大きくクローズアップされるに至った。

この問題は我が国の精神医学・医療のあり方を 問うような深刻な問題も孕んでいる。また、精神 医学の重要な一分野である司法精神医学のあり方 についても検討すべき事柄を含んでおり、今後、
精神医学研連でも取り上げるべき重要課題である。 そのような視点から今回の事件の背景にある問題 点を整理し、取るべき対策について私見を述べて みたい。

\section{犯罪を犯した精神障害者への対応の現状}

精神障害者が犯罪を犯した時には、警察は犯罪 者を検察に送検し、精神鑑定を行う。責任能力が ありとなれば、起訴され裁判を受けた後、医療刑 務所で服役することになる。しかし、現状ではそ の90\%が責任能力なしとの理由から不起訴処分と され、検察官は精神保健福祉法に基づき都道府県 知事に通報し、二人の精神保健指定医の診察の結 
果、自傷他害の疑いがあれば措置入院となり、そ うでなければ無罪釈放される。一旦起訴されても、 疑義が生じて再鑑定が行われた結果、犯行当時心 神培失とみとめられれば、これも都知事に通報さ れ精神医療システムで対応される。

入院した触法精神障害者は症状が軽減し自傷他 害の恐れがなくなった時には、主治医の判断で措 置入院を解除して退院となる。あるいは患者が精 神医療医療審査会に退院要求を行い、それが認め られれば退院となる。退院後は外来通院となるが、 保健婦や精神保健福祉士などによる患者の服薬や 地域生活へのサポートは十分ではない。

\section{現状の問題点}

上記のシステムでは以下の点が問題となる。

1. 治療、処遇の必要上、早急に精神医療システム へ移送するため、簡単な鑑定 (簡易鑑定)で責任 能力の有無を判断する。しかし、刑事責任能力 の判定は簡易鑑定では困難なことが多い。

2. 刑事司法内で鑑定留置をして時間をかけて精神 鑑定を行おうとすると治療への導入が遅れる。

3. 犯罪を犯しても9割が不起訴となっている現状 では、精神障害者の裁判を受ける権利が保証さ れない。

4. 一度、不起訴処分が出されると、たとえ精神医
療システムの中で判断の誤りに気づかれても刑 事司法システムに戻すことが不可能である。

5. 違法薬物の急性中毒のため、不起訴になった場 合には、治療して症状が改善した後でも違法薬 物使用に対する追訴ができない。

6. 措置入院患者の退院が主治医一人の判断に任せ られており、判断の妥当性が保証されない。ま た、退院後、犯罪を犯した場合、往々にして主 治医が非難されるため、過度に入院を続けてし まう。

7. 医療刑務所では精神保健福祉法に基づく精神医 療が行われていないため、患者の人権が守られ ない恐れがある。

8. 我が国の精神医療体制に不備があり、精神病院 でも医療刑務所でも十分なスタッフ配置のもと で適切な医療が行われているとは限らない。

9. 障害者が退院した後のフォロー、支援が十分に 行われず、これが再犯に結びつく可能性がある。

\section{我が国の精神医療の問題点}

ここで我が国の精神医療の問題点のうち特に重 要なものを整理して打く。まず、診療報酬が低く 抑えられていることである。これは精神科医療の 特徴として、身体疾患に見られるような目に見え る形での技術がないという理由による。これと関 
連して、精神科診療にかかわる医療者の数も低い ままで認められてきた。一般科では患者数 16 に対 して医師数が 1 名、看護者は患者 3 名に対して 1 名の ところを、精神科では患者48名に詨して医師1名、 看護者は患者 6 名に対して1名という、いわゆる精 神科特例というものがまかり通ってきた。最近行 われた第4次の医療法改正でもこの問題は大きな改 善はみられなかった。

精神障害者の福祉施策も立ち遅れており、知的 障害や身体障害に比べて、社会資源が圧倒的に少 ない。そのために退院後の社会生活が円滑に行か ず、退院してもすぐに再入院という結果になるこ とが多い。さらに精神障害者に対しての偏見が根 強くあり、障害者の社会復帰を阻んでいる。例え ば、グループホームを地域に建設しようとしても、 地域住民の反対で建設が進まないというような実 態がある。

以上述べた事柄は、触法精神障害者が十分な医 療や福祉を享受できないという点で、再犯率を高 めている可能性がある。この点が精神障害者の犯 罪を防ぐためにも、精神医療の底上げが必要であ るという説の根拠になっている。

\section{当面の解決策の提案}

問題解决には2つの段階を踏む必要がある。第一
は触法精神障害者対策であり、これは早い時期に 行う必要があろう。第二段階として、精神医療の 底上げを図ることである。第二段階は第一がすん でからというのではなく、並行して進めるべき問 題である。

まず、肝要なことは、触法精神障害者への対応 は社会的防衛ではなく人権擁護の立場から行うこ とである。最初に行われなければならないのは、 犯罪を犯した時点の責任能力の鑑定である。これ はこれまでのような短時間の鑑定ではなく、十分 経験豊かな精神科医が時間をかけて行うべきであ る。この際、鑑定能力を高める医師側の努力が必 要になる。また、必要な治療への導入を速やかに 図れるように、鑑定を精神科病院で行うことも考 慮されるべきである。

さらに責任能力なしの判定が出された後の処遇 については、司法を交えた専門家グループによる 評価を行って決定する。治療の必要が認められれ ば強制入院となるが、入院中に行われる治療につ いては、その適正さと透明性を図る意味から、第 三者機関の定期的な評価が必要である。さらに強 制入院を解除する時にも、これまでのような一人 の主治医の判定によるのではなく、入院の是非を 決定する時と同様に、司法を交えた専門家グルー プによる評価が再び行われることが重要になる。 


\section{論 壇}

社会復帰した後には、精神保健福祉士を中心にし たサポートチームによる、医療と生活援助が行わ れなければならない。社会復帰後の医療の継続は 重要であるから、その継続を保証するような法的 措置を講じることは効果的かも知れない。

このような体制を構築し、精神障害者の犯罪を 未然に防ぎながら、精神医療の底上げを行うこと が不可欠である。もし、上記の触法精神障害者へ の対策のみに終わり、精神医療全体の改善がなけ れば、触法精神障害者対策は不完全に終わるであ ろう。何故ならば、精神障害者全体に対する十分 な支援システムがあってはじめて、精神障害者の 犯罪を未然に防ぐことが可能になるからである。

\section{我が国の司法精神医学の確立の重要性}

我が国における精神障害者の重大犯罪への抜本 的な対策は司法精神医学の確立を待たなければな らない。現在、司法精神医学を専門とする者は数 が少ない。大学関係でも専門家は5指に足りない有 様である。そして、大学に打ける司法精神医学の 教育は極めてそしい。

司法精神医学の課題は、精神障害者の犯罪の実 態の把握、信頼性の高い鑑定方法の確立、精神障 害者の犯罪予測性の研究、触法精神障害者にかか わる医療および司法システムの確立、人格障害と
犯罪との関連性、精神障害者の人権と被害者およ びその家族の人権、など多数に上る。これらの課 題については実証性に富む資料は少なく、着実な 研究がこれから行われなければならない。そして、 学生や若い精神科医に対する司法精神医学の教育 も忘れてはならない重要課題である。

高楅 清久（たかはし きよひさ 1938年生）

日本学術会議第7部会員、国立精神・神経センター総長 専門：診療科学、精神医学 